\title{
Oligocene-Pleistocene Paleogeography Within Banyumas Basin and Implication to Petroleum Potential
}

\author{
Eko Bayu Purwasatriya ${ }^{1 *}$, Sugeng Sapto Surjono ${ }^{2}$, and Donatus \\ Hendra Amijaya ${ }^{2}$
}

1 Geological Engineering, Faculty of Engineering, Universitas Jenderal Soedirman, Jl. Mayjen Sungkono, Km.5, Blater, Purbalingga, 53371

2 Geological Engineering Department, Faculty of Engineering, Universitas Gadjah Mada, Jl. Grafika No.2, Yogyakarta, 55281

*e-mail: bayusatriya@yahoo.com

\begin{abstract}
This study attempts to reconstruct paleogeography of Banyumas Basin in association with magmatic arc evolution and its implication to petroleum potential. Based on the volcanic rock distribution, their association and relatives age, there are three alignments of a magmatic arc, that are: (1) Oligo-Miocene arc in the south (2) MioPliocene arc in the middle (3) Plio-Pleistocene arc in the north. The consequences of the magmatic arc movement were tectonic setting changing during Oligocene to Pleistocene, as well as their paleogeography. During Oligo-Miocene where magmatic arc existed in the southern part, the Banyumas tectonic setting was a back-arc basin. This tectonic setting was changing to intra-arc basin during MioPliocene and subsequently to the fore-arc basin since Plio-Pleistocene until today. Back-arc basin is the most suitable paleogeography to create a depositional environment for potential source rocks. Exploration activity to prove the existence of source rocks during Oligo-Miocene is needed to reveal petroleum potential in Banyumas Basin.
\end{abstract}

\section{Keywords}

Back-arc Basin, Banyumas Basin, Magmatic arc, Paleogeography, Petroleum potential

\section{Introduction}

Citation: PurwasatriyaE. B., Surjono S. S., D. H. Amijaya.: Oligocene-Pleistocene paleogeography within Banyumas basin and implication to petroleum potential. In: I.W. Mustika, I. Kartini. (eds.): Proceeding of the 3rd International Conference on Science and Technology, Vol. 1, pp. 45-51. UGM Digital Press Physical Science and Engineering, Yogyakarta (2018).

Published: October, 2018

Banyumas basin is one of a sedimentary basin in the southern coast of Central Java, Indonesia. Banyumas is also categorized as frontier basin because although oil and gas seeps found, its potential economic petroleum has not yet revealed. The previous researcher called Banyumas Basin as Terra Incognita, a place that has not yet fully understood in terms of its petroleum systems [1]. It is important to know how the petroleum system works in Banyumas basin and one step to understanding it better is by studying the paleogeography of Banyumas basin from time by time. Paleogeography means in this sense relates to its position to a magmatic arc. If the position of the basin is in front of a magmatic arc and directly face opening sea, it is called the fore-arc basin. If the position of the basin is situated among 
the mountains on the magmatic arc, then it is called intra-arc basin. If the position of the basin is in the back of a magmatic arc, it is called back-arc basin. Fore-arc basins are marine depositional basins on the trench side of arcs, and back-arc basins occur over descending slabs behind arc systems [2] (Fig. 1). In petroleum systems, back-arc basin and intra-arc basin are the paleogeography which has an important role to create a petroleum source rock. Petroleum source rock is usually a fine grain rock, contain sufficient organic matter and will mature by thermal conduct. In back-arc and intra-arc basin, the depositional environment is quite of current and wave, thus the fine grain sediments can be deposited rapidly, and the organic matter also can be preserved in a reduction environment. Banyumas basin indicates a change in its paleogeography throughout different geological time. The indication is visible by the distribution of volcanic rock with different age and shaped into an alignment. The geological study is needed to find the evidence in the surface, and geophysical data such as gravity data is needed to support the interpretation by providing the subsurface data. Therefore, the integration of geology and geophysical data will increase the confidence of the interpretation.

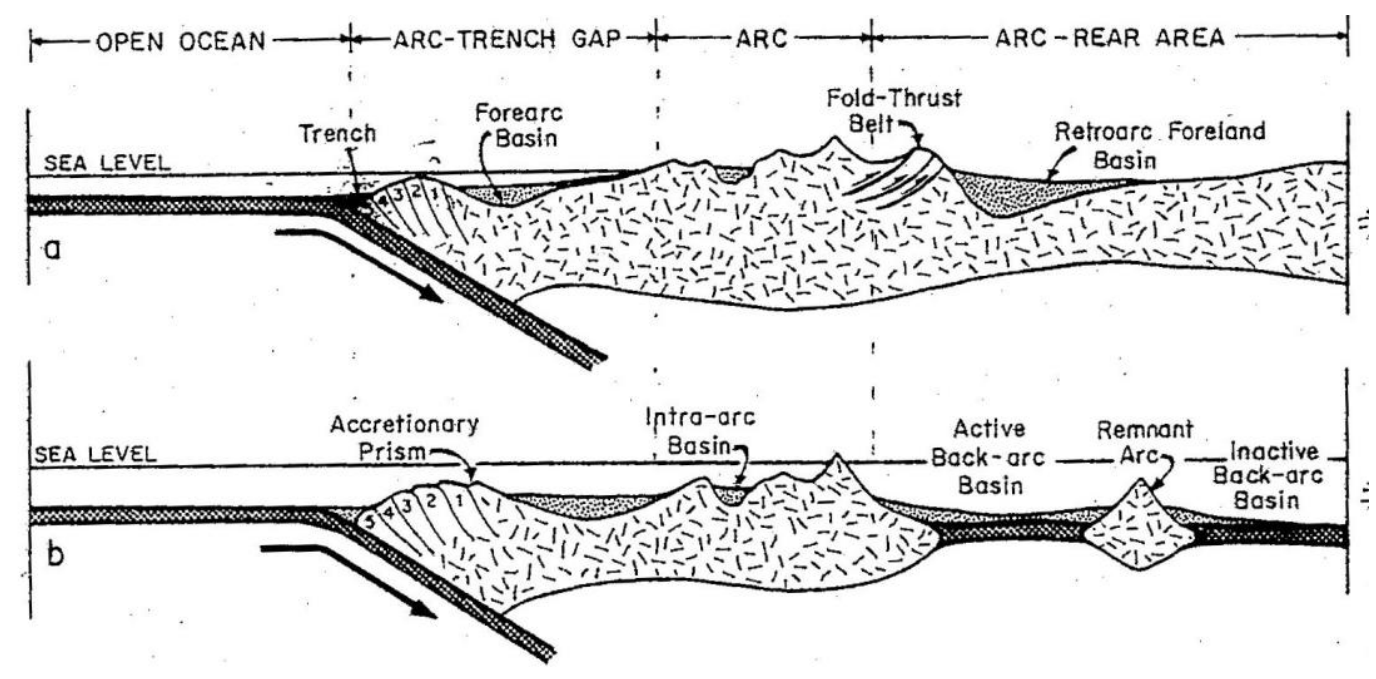

Fig. 1 Diagrammatic cross sections of (a) continental margin and (b) island arc, showing fore-arc basin, intra-arc basin and back-arc basin [2].

\section{Methods}

The methods are divided into two parts, first is the geological method and the second is a geophysical method. The geological method is conducted to obtain the surface data, such as lithology, stratigraphy and structural geology and geophysical method is to provide the subsurface data. The geological method comprises of fieldwork and studio analysis. In this sense, a fieldwork means a general geological surface mapping to identify the type of lithology that indicates the volcanic product and the location, to determine whether it is made of alignment of magmatic arc or not. A studio analysis means the making of the general geological map from the fieldwork and analyze the type of rock samples obtained from the field. The use of Banyumas age data, particularly age of its rock is adapted from the previous researcher. The necessary data for the geological methods are:

- Regional geological maps for Banyumas and the surrounding area, scale 1:100,000

- Topographic maps for Banyumas and the surrounding area, scale 1:25,000

- $\quad$ Literature from the previous researcher for references

The tools needed for geological fieldwork comprises of Geological Compass, Geological Hammer, Loupe, GPS, Camera, Stationery, Field books, medicine, and other personal needs.

The second method is the geophysical method. The geophysical method means in this study is the gravity method. Gravity data is taken from the topex website http://topex.ucsd.edu/cgi-bin/get_data.cgi [3]. It is a satellite gravity data and can be downloaded for free. Approximately 1,800 point of gravity data of Banyumas and its surrounding area were downloaded and needed to proceed for a gravity anomaly map. The step of gravity processing data is provided on (Fig. 2). Figure 2 shows the steps from acquisition data to regional and residual anomaly maps, but, if we download the data from topex's website, the data 
already a free-air anomaly, so the step is shorter than the flow diagram. The gravity data will support the analysis and interpretation of magmatic arc from subsurface information. The gravity works based on the contrast density of rocks in the subsurface and volcanic rocks have a higher density than other sedimentary rocks. The regional anomaly gravity usually used to identify the deep anomaly such as the border of a paleobasin and the residual anomaly gravity usually used to identify the shallow and local anomaly. This study utilized the residual anomaly to detect the alignment of the paleo-magmatic arc and matching the interpretation with the geological surface data. The integration of surface data from the geological study and subsurface data from gravity interpretation should give better results to define the alignment of the paleo-magmatic arc and then interpret the paleogeography of the basin throughout its geological time.

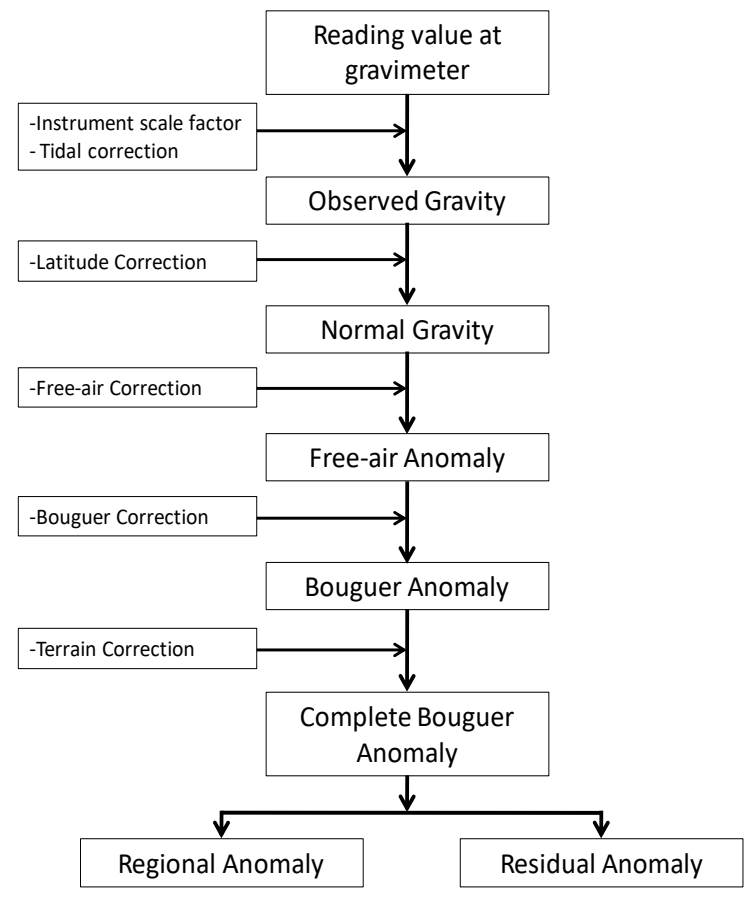

Fig. 2. Flow diagram of gravity processing to get the regional and residual anomaly maps

\section{Results and Discussions}

Geological fieldworks and studio analysis had been conducted in Banyumas area. Some association of volcanic rocks found and made an East-West alignment based on its relative age. Association of volcanic rocks related to the central zone and proximal zone of a magmatic arc are breccia, lava, intrusion dike or sill. Association of volcanic rocks related to the distal zone of magmatic arcs such as tuff, marl, tuffaceous sandstone, siltstone, and claystone. Figure 3 shows an example of volcanic rocks in the field. Figure 3(A) is a very rare kind of breccia; it is called limestone breccia. It is indeed so because usually limestone is not associated with breccia and in this case, the fragment of breccia is andesite, and the matrix of breccia is limestone. It probably happens when volcanic activity is shut off, so carbonate reef can build up, but there is a small volcanic activity like diatreme made explosive and mixed with reworked carbonate reef. Figure3(B) is a "common" breccia, called andesite breccia, composed of andesite as fragments and sandstone as a matrix. Andesite breccia is distributed almost at all magmatic arc alignment but with different geological age. Figure 3(C) shows the magmatic intrusion in a limestone. The intrusion indicates magmatic activity near the central zone of a magmatic arc. Figure 3(D) shows the volcaniclastic rocks, intercalation of tuffaceous sandstone and siltstone. The volcaniclastic rocks usually indicate the distal zone of the magmatic arc. 


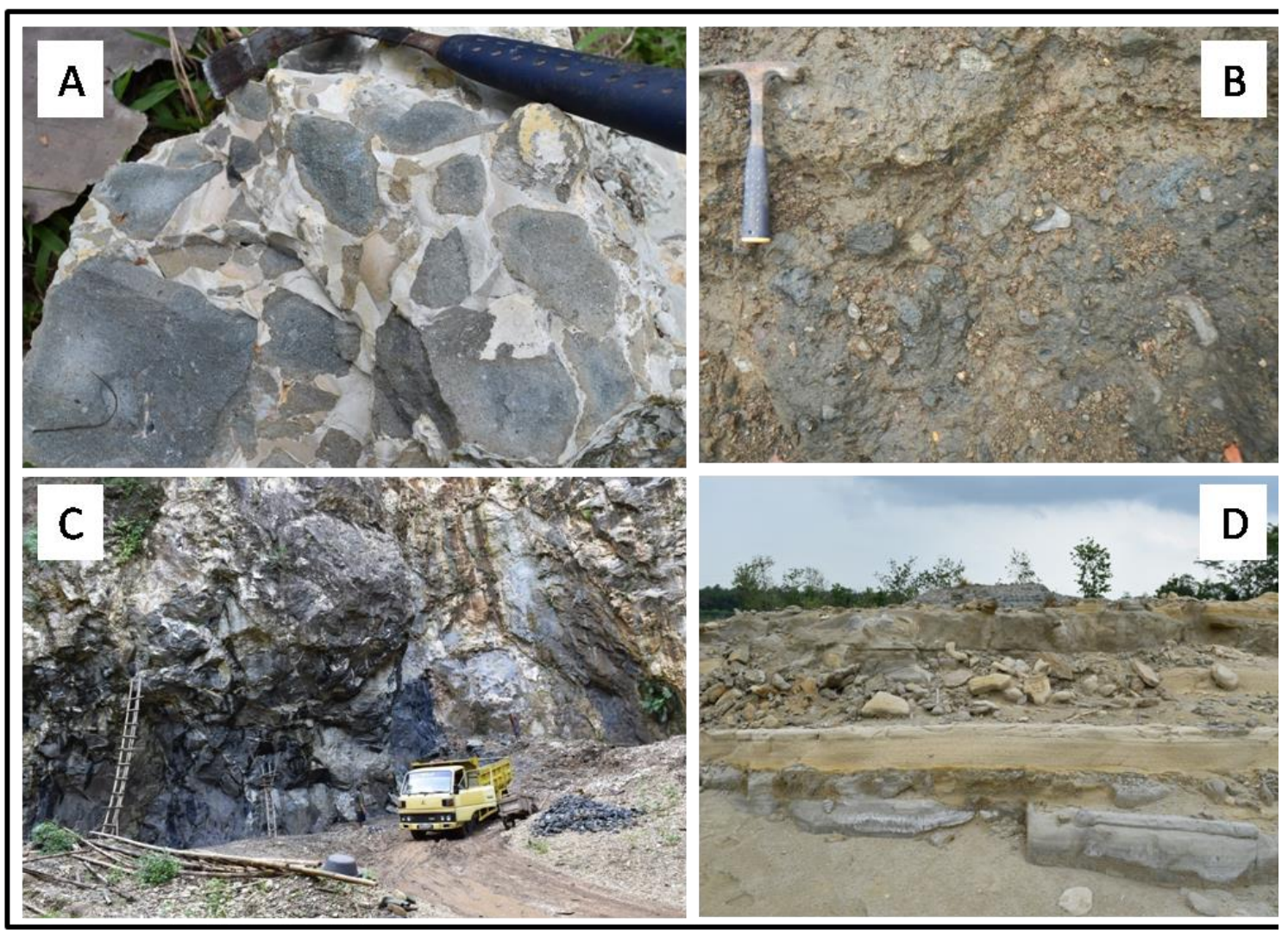

A fieldwork and studio analysis resulted in the production of regional geological maps of Banyumas and its the surrounding that are shown in (Figure 4). The picture in figure 4 is slightly complex due to large area, but the maps are equipped with map legend to provide the explanation of the figure for a better comprehension of meaning. The various range of color from red to brown shows the association of volcanic rocks such as breccia, lava, and intrusion, means that the area is near magmatic arc. The various range of color from yellow to green is showing the volcaniclastic rocks such as tuff, marl, tuffaceous sandstone, siltstone, and claystone, means the area probably a distal zone or far zone of a magmatic arc. The blue color means limestone and grey color means alluvium. The brown line crossing the map is structural geology such as a fault or fold axis, and the blue curve is a delineation of Banyumas Basin taken from [4]. This geological map is modified from the previous regional geological map such as Banyumas area [5], Purwokerto and Tegal area [6], Majenang area [7] and Pangandaran area [8]. There area three alignment of magmatic arc in Banyumas basin and bordered by the black dashed line in the geological map. The first alignment is in the south of Banyumas basin, called Oligo-Miocene magmatic arc. The second alignment is in the middle of the basin, called Mio-Pliocene magmatic arc and the third alignment is Plio-Pleistocene magmatic arc in the north of the basin. Oligocene was around 33.9 million years ago, Miocene is around 23 million years ago, Pliocene is around 5.3 million years ago, and Pleistocene is around 2,6 million years ago [9]. Based on the position of a magmatic arc, the paleogeography of Banyumas basin change through geological time. At Oligocene-Miocene, the paleogeography probably a back-arc basin if the basement is continent or an island arc if the basement is the oceanic crust. At Miocene-Pliocene time, the paleogeography probably an intra-arc basin and at Pliocene-Pleistocene the paleogeography becomes a fore-arc basin until now. Moreover, Banyumas basin still has the petroleum potential, in 2010 a water well drilling found oil at depth 90 meters, in Tipar Kidul village, Ajibarang Subdistrict, Banyumas regency [10], this proved the interesting challenge for the Banyumas basin and also its petroleum potential. 


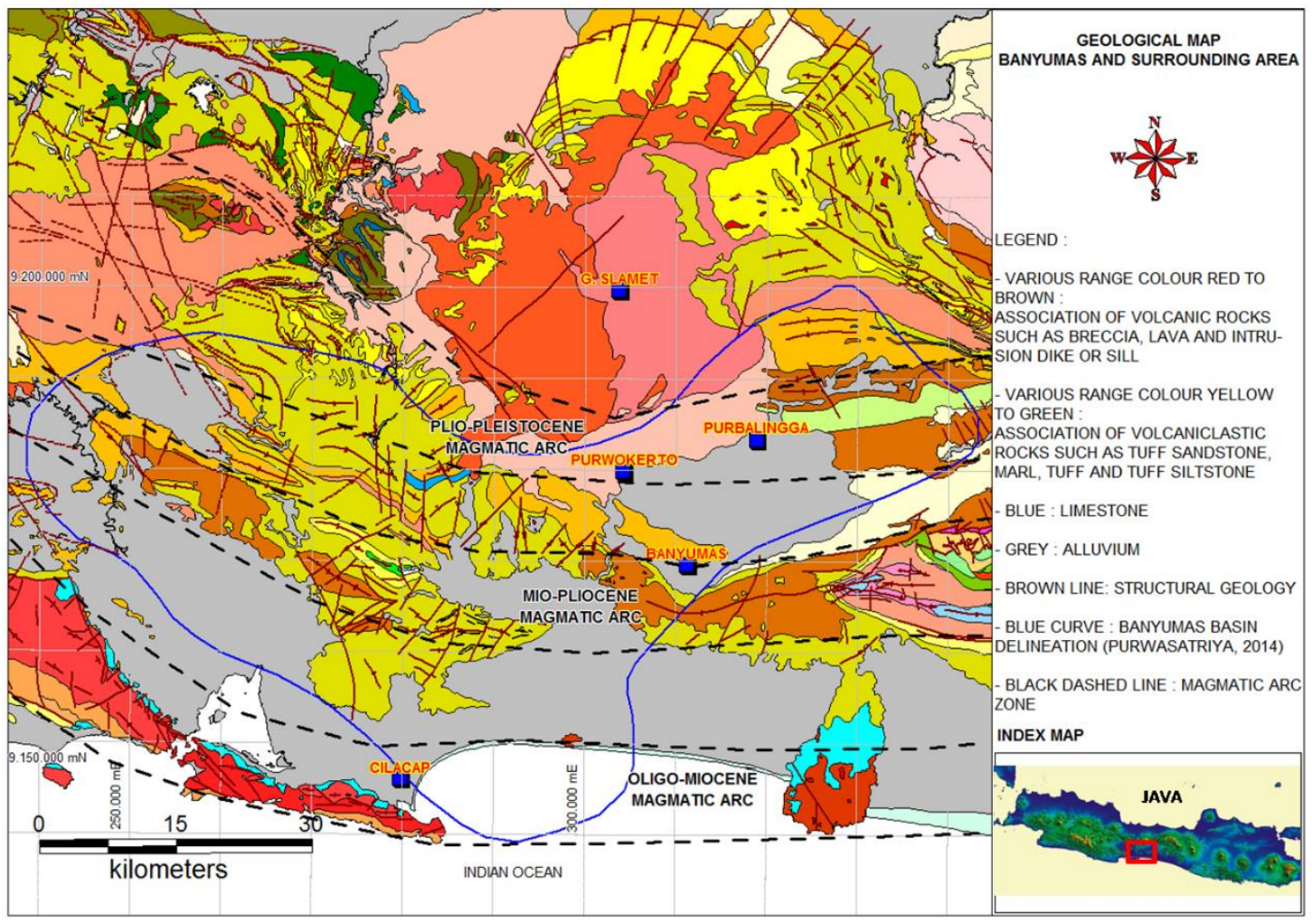

Fig. 4 The geological map of Banyumas and its surrounding area shows basin delineation and three alignments of a magmatic arc

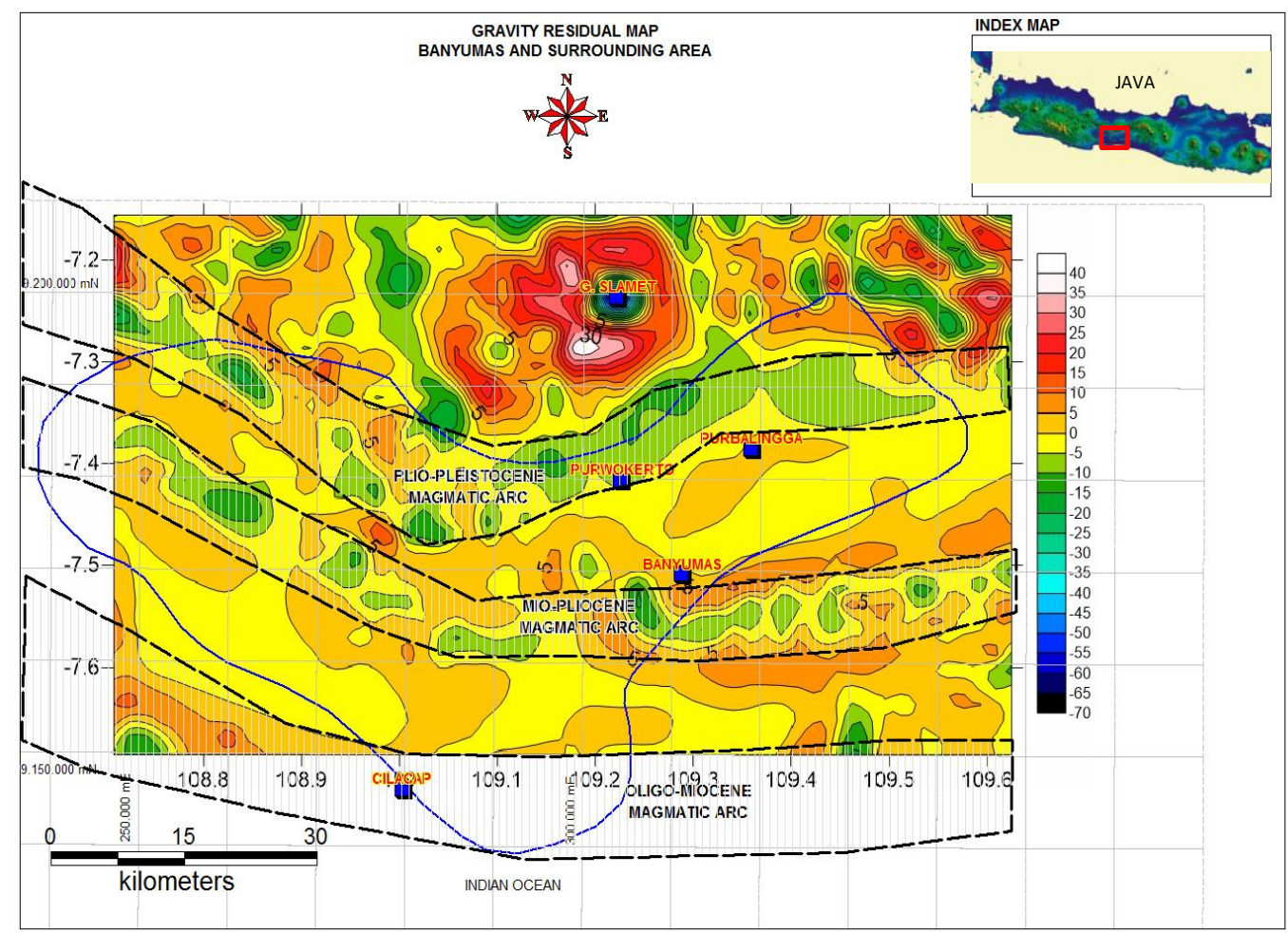

Fig. 5 Gravity residual map showing the three alignments of magmatic arc indicated by a low anomaly (green) among high anomaly (orange) 
The geophysical method creates a residual gravity map and regional gravity map, but in this study, only the residual gravity map used to support the interpretation of alignment of magmatic arc from surface data. The gravity residual map (Fig. 5) also shown the alignment of three magmatic arcs, similar to the geological map. The low anomaly with green color among high anomaly with orange color interpreted as a mountainous arc. This interpretation based on Slamet mountain in the north of Banyumas basin that gives the same response, a low anomaly among high anomaly. It can be understood due to gravity works based on the density of medium and mountains will have a hole in the middle of it is cone filled with soft sediments and give low anomaly respond in gravity. The flank of the cone usually consists of breccia, lava, and intrusion which are high in density with high anomaly response in gravity.

\section{Conclusions}

There are three magmatic arcs within Banyumas basin, first is Oligo-Miocene magmatic arc in the southern part of the basin, second is Mio-Pliocene magmatic arc in the middle of the basin, and third is Plio-Pleistocene magmatic arc in the northern part of the basin. The movement of the magmatic arc through geological time, giving implication to the paleogeography of Banyumas basin. At Oligo-Miocene, the paleogeography probably back-arc basin or island arc, at Mio-Pliocene the paleogeography probably intra-arc basin and at Plio-Pleistocene the paleogeography should be fore-arc basin. Back-arc basin and the intra-arc basin is the most suitable paleogeography for petroleum potential because the environment is quite of current and wave, so, the fine grain sediment and organic matter can be deposited and preserved. By burial for million years, the temperature will increase, and the organic matter should be mature and converted to petroleum. A petroleum source rock that had been mature and full of petroleum will expel to carrier bed like sandstone and migrate to a trap consist of the good reservoir. There needs to be more investigation about the petroleum systems in this area in order to determine a prospect of petroleum.

Acknowledgments I would like to thank Geological Engineering Department, Faculty of Engineering, Universitas Gadjah Mada and Geological Engineering, Faculty of Engineering, Universitas Jenderal Soedirman.

\section{References}

[1]. Satyana, A.H., Central java indonesia-a'terra incognita' in petroleum exploration : new consideration on the tectonic evolution and petroleum implication, Proceedings Indonesian Petroleum Association, 31st annual convention Jakarta,pp. 105-126 (2007). DOI: 10.29118/IPA.1211.07.G.085

[2]. Kent C. Condie, Plate Tectonics and Crustal Evolution, Fourth Edition, Butterworth-Heinemann, Oxford (1997). https://doi.org/10.1016/B978-0-7506-3386-4.X5000-9

[3]. Topex (2014), Extract XYZ Grid - Topography or Gravity, http://topex.ucsd.edu/cgi-bin/get_data.cgi, Accessed: May, 2014

[4]. Purwasatriya, E.B., Tinjauan kembali potensi hidrokarbon Cekungan Banyumas berdasarkan data geologi dan geofisika, Proceeding Seminar Kebumian Ke-7, Yogyakarta (2014). https://www.academia.edu/29740002/TINJAUAN_KEMBALI_POTENSI_HIDROKARBON_CEKUNGAN_ BANYUMAS_BERDASARKAN_DATA_GEOLOGI_DAN_DATA_GEOFISIKA

[5]. Asikin, S., Handoyo, A., Prastistho, B., dan Gafoer, S., Peta Geologi Lembar Banyumas, Jawa, Pusat Penelitian dan Pengembangan Geologi, Bandung, Indonesia (1992) http://library.vsi.esdm.go.id/katalog/slims7_cendana-master//index.php?p=show_detail\&id=11478

[6]. Djuri, M., Samodra, H., Amin, T.C., dan Gafoer, S., Peta Geologi Lembar Purwokerto Dan Tegal, Jawa, Pusat Penelitian dan Pengembangan Geologi, Bandung, Indonesia (1996) https://www.dropbox.com/s/q1n6fgqy11bvw29/22-1308-6-1309-3Purwokerto\%20dan\%20Tegal.jpg?dl=0

[7]. Kastowo, Peta Geologi Lembar Majenang, Jawa, Direktorat Geologi, Bandung, Indonesia (1975). https://www.dropbox.com/s/lxyl9vlymsyxvti/20-1308-5-Majenang.jpg?dl=0

[8]. Simandjuntak, T.O., dan Surono, Peta Geologi Lembar Pangandaran, Jawa, Pusat Penelitian dan Pengembangan Geologi, Bandung, Indonesia (1992). https://www.dropbox.com/s/dyeglqt4ek3m8ig/21-1308-2-Pangandaran.jpg?dl=0 
[9]. Walker J.D., Geissman, J.W., Bowring, S.A., Babcock L.A., GSA Geologic Time Scale v. 4.0, Geological Society of America, America (2012).

https://www.geosociety.org/GSA/Education_Careers/Geologic_Time_Scale/GSA/timescale/home.aspx

[10]. Purwasatriya, E.B., and Waluyo, G., Studi Potensi Minyak Dangkal dengan Pendekatan Metode Statistik Berdasar Data Geologi Permukaan Di Cekungan Banyumas, Jurnal Dinamika Rekayasa, Vol.8 No.2 (2012). DOI: http://dx.doi.org/10.20884/1.dr.2012.8.2.103 